\title{
Surfaces
}

\section{NOTES TOWARDS A POLITICS OF "AMERICAN" CRITICISM}

\section{Paul A. Bové}

Volume 1, 1991

URI : https://id.erudit.org/iderudit/1065252ar

DOI : https://doi.org/10.7202/1065252ar

Aller au sommaire du numéro

Éditeur(s)

Les Presses de l’Université de Montréal

ISSN

1188-2492 (imprimé)

1200-5320 (numérique)

Découvrir la revue

Citer cet article

Bové, P. A. (1991). NOTES TOWARDS A POLITICS OF "AMERICAN" CRITICISM. Surfaces, 1. https://doi.org/10.7202/1065252ar

\section{Résumé de l'article}

Une réflexion sur la nature de la critique oppositionnelle et les problèmes de l'opposition à l'intérieur et à l'encontre de la discipline et du discours des Études Américaines. d'utilisation que vous pouvez consulter en ligne. 


\title{
NOTES TOWARDS A POLITICS OF
}

\section{"AMERICAN" CRITICISM}

Paul A. Bové

\begin{abstract}
A meditation on the nature of oppositional criticism and the problems of opposition within and to the discipline and discourse of "American Studies".
\end{abstract}

\section{RÉSUMÉ}

Une réflexion sur la nature de la critique oppositionnelle et les problèmes de l'opposition à l'intérieur et à l'encontre de la discipline et du discours des Études Américaines.

It is certain that they [American industrialists] are not concerned with the "humanity" or the "spirituality" of the worker, which are immediately smashed. This "humanity and spirituality" cannot be realised except in the world of production and work and in productive "creation." They exist most in the artisan, in the "demiurge," when the worker's personality was reflected whole in the object created and when the link between art and labour was still very strong. But is is precisely against this "humanism" that the new industrialism is fighting. "Puritanical" initiatives simply have the purpose of preserving, outside of work, a certain psycho-physical 
equilibrium which prevents the physiological collapse of the worker, exhausted by the new method of production.

This equilibrium can only be something purely external and mechanical, but it can become internalised if it is proposed by a new form of society, with appropriate and original methods... It is in their [American industrialists'] interests to have a stable, skilled labour force, a permanently well-adjusted complex, because the human complex (the collective worker) of an enterprise is also a machine which cannot, without considerable loss, be taken to pieces too often and renewed with single new parts.

Antonio Gramsci, The Prison Notebooks (p. 303)

One should never write in the abstract about the nature of "oppositional criticism." "Criticism" of any sort must always be concrete and specific, no matter how theoretically informed. "Oppositional criticism," particularly, cannot be defined or theorized so much as it must be enacted. Only because academic criticism is carried out so often in a professionally and institutionally social space could one even imagine a "general theoretical discussion" of "oppositional criticism." Whenever oppositional critical work is done, it is always specifically placed (conjunctural) and so cannot be treated as a matter of "theory" rather than as the concrete form of

practice it must be to be itself. Furthermore, if, as R. P. Blackmur always had it, criticism is a social gesture, highly contextualized, or "overdetermined," then it cannot be "defined" or "debated;" it cannot be "represented" except by and as an enactment, a "dramatization" --in Blackmur's word-- that engages specifically with the object of its critique.

There are several reasons why "oppositional criticism" must be enacted rather than abstractly "theorized." Most important among them is the fact that the "profession" has an uncanny ability to adopt its seemingly most stringent critics by recycling their values and methods, transforming them into new "fashions" for replication and reward. That this could be the fate of "oppositional criticism" -- if the notion is taken up in the abstract and made merely the subject of articles without consequence -- no one should doubt. The genealogy of the "oppositional" makes it readily available for such recirculation [1]. "Oppositional criticism" should not be confused with an attitude of generalized dissatisfaction with the profession or the culture; it is not merely a weak effect of alienation and commodification. It should, I think, be differentiated from any proverbial articulation of attitudes towards values, institutions, and "life situations;" one thinks here of a tradition that extends from Kenneth Burke to Wayne Booth[2] . Nor does "oppositional 
criticism" train us to see literature as a way better to deal with the problems of modern life.

To catch something of the force of an "oppositional critical" act, one must see first of all see it as an act and in action; one must see it engaging critically with some element of the empowered structure of the society and culture against which it takes up its stance. One must see it not as just a "force for change and betterment" but as a relentless even if sometimes admiring but implacable agonism, as an indecorous enemy if you will. One cannot, therefore, speak merely generally to the topic "what would 'oppositional criticism' of American literature and culture be"; one must "instantiate" that criticism for, in its "oppositional" position, it cannot exist as a series of generalities, of prescriptive statements laying out a program, method, or set of "values." We cannot forget that Marx and Nietzsche teach intellectual warfare: critical instruments are weapons --even for those who argue so hard to deny the fact; especially so despite the ease with which many professionals so easily concede the fact. "Oppositional criticism" can only be found at those places where these weapons are brought to bear on just the entrenched values, interests, and practices of professionals and institutions important to the academy and so to its effects upon and roles within the larger socius.

It is with these thoughts in mind that I give attention in the following pages to some of the work of Sacvan Bercovitch. His institutional distinction and his critical ambition bring him to attention as a figure to interrogate if one wants to mark some of the limits and possibilities of the criticism of "American literature."[3] Pointing to some of these limits and possibilities helps develop an image of "Americanist" criticism as emerging from a set of assumptions, values, practices, technologies, institutions, and languages --all relatively systematic, all interrelated-- that suggest a link between a certain kind of rationality and certain more material,

historical interests of a sort that need to be opposed for the political consequences of their link with that rationality. They need to be opposed if the possibility of a different order and organization of knowledge, self, and society is to be recalled and perhaps made possible.

\section{II}

Never before has so much of the study of "American" literature and culture been as critical of the classical forms of "American" writing and the dominant forms of "American" society as it is now. Bercovitch puts the 
matter succinctly when he says that the new generation of "Americanists" does not separate the "America of the spirit, represented by our classic writers, from the realities of American life, represented by ideologues and their victims."[4] Of course, in this day and age, the right-wing does not want for followers who might challenge this "New Americanist" critical

history.[5] The conservatives quite precisely bemoan the "New Americanists" double ideological challenge: to the established disciplinary, discursive procedures that, in fact, depend upon the separation of the two forms of representation Bercovitch names; and to the liberal, pluralist ideology that that discipline's discourse reproduces and distributes in a normalizing relationship to the State and the constantly "new society" produced by "American" capitalism.

Everyone now knows the names of the books and critics that the profession feels have broken open the canon of "American" literature and reformed the ways in which that literature and its place in "American" cultural history is to be thought about[6]. Most agree that feminist revisions of history and feminist readings - --including concerns with literacy--as well as objections to the "androcentric"[7] discourse of "American" studies itself have done most to reorganize

the production of knowledge about our culture. Feminism has shown how women and their writing have been excluded from and by the valued realm of the "classic," and so extended the hermeneutics of suspicion to the term itself. In the process, an entire body of literary and cultural production has been recovered from the historical amnesia enforced even by such generously powerful texts as American Renaissance[8] and they have helped us to understand the power structures and determinative effects of the gender bias of "American Studies'" discourses, themselves. In addition, of course, recovering the work of "scribbling women" has paradigmatically helped us understand how polymorphous, how differentiated, how filled with resistance and alternative forms of creation the once apparent monolith of "American literature and culture" has always been.

Feminism, of course, has not been alone in this remaking of "American Studies." The new attention to minority --black, Hispanic, and Amerindian writings-- has drawn our attention to the international nature of our history, to its founding involvements with other cultures of Africa and Latin America, as well as to our society's long history of extermination and imperial aggression. In the reading of black women's writing, many critics feel the questions of class, race, and gender can be uniquely studied to get a clear sense of the workings of powerful, authoritative, and complex structures of oppression and resistance. 
It would seem, in other words, that in the very recent past, "Americanists" have come far towards meeting Edward W. Said's more than decade old definition of real oppositional criticism: it must be "actively generated out of a genuine historical research" and it must be "ultimately fixed for its goals upon understanding, analyzing, and contending with the management of power and authority within the culture."[9] There is now enough critical energy being devoted to critiques of the origins of "American liberalism" in relation to the "self" in laissez-faire economics that we have no fear that the relations -- sometimes oppositional, sometimes supportive -- of our literary masters to the often awful forms of "American" political and social life will ever be forgotten.

Jonathan Arac has said that Sacvan Bercovitch's American Jeremiad should make it impossible for anyone to use easily the word "America."[10] And, indeed, obsolete as well as neo- conservatives agree that the "New Americanists" -- perhaps like the flag burners of whom we have recently heard so much -- have no respect for the achievements of "American" culture and society. Often these conservatives disguise themselves as pluralists.[11] And as "pluralists" they are often challenged, in turn, by ideology-critique and by historicist recoveries of the "real differences" that exist within, but are often forgotten by, the recorders of "American" culture. For the most part, though, the future of "American" criticism of "American" literature and culture seems secure; we are, in a way, talking of generational change here and, the future, of course, belongs to the young.

\section{III}

Bercovitch suggests some of the problems and possibilities in the New Americanism: "America" has a habit of making it new, and although making it new --through ideology critique or historical recovery or whatever powerful critical device-- cannot be trusted to provide us with any way out of the wilderness of the "American" ideology, it can move us toward "an alternative future" (A 439). Summarizing his sense of the value of the essays collected in Ideology and Classic American Literature, Bercovitch is unusually optimistic: "I would like to think... that among these ["the richness of the problems at issue, the methodological and practical challenges involved in these inquiries"] is the challenge of alternative ways of intellectual, moral, and political commitment" (A 439). Bercovitch clearly would like to think... But what are the problems that lead Bercovitch to express this relatively minimal (and desperate) desire in the face of his critical intellectual analysis --an analysis that suggests quite precisely the opposite outcome to this "New Americanism"? 
Bercovitch remains interesting because --from the center of the profession, as it were-- he so clearly and usefully lists what he takes to be the definitive problems molesting any "Americanist" critical project. As he puts the issues they do seem compelling; that he sees them molesting even the authoritative work of the brightest "New Americanists" gathered in his volume attests to the gravity of the issues in his vision and to the compulsive force of his final expression of desire. Yet the problems he imagines are not the final problems. Were we to mistake them for the most basic problems, we would lead ourselves to two unsatisfactory results: a persistent concern with the epiphenomenal that would be always preliminary to an "American" criticism; or, more dangerously, to institutionalizing a politically and aesthetically reductive model of critical practice. We would replicate the already established discipline by not querying its precise genealogical, discursive relations --even in its "oppositional" moments-- to the State, to the dominant forms of

rationality, and to the institutions of "American" culture. In other words, and to put the matter crudely, to take Bercovitch's problems as "radical" would allow us to avoid describing, theorizing, politicizing, and where possible resisting and reorganizing the forms and institutions that treat "American" literature and culture as a "subject" of knowledge. That is to say --and still too simply-- Bercovitch's are problems of "content," of the "representations" "within" ideology, problems of "consciousness" that can be dealt with in "reforming" modes, by adjustment and adjudication within the ongoing terms and institutions of "American Studies," "American" culture, and the "American" State. His "problems" are not radical precisely because they do not and cannot lead to a new set of rationalities and practices or to a new politics. He can merely imagine the possibility that some "Truly New Alternatives" will emerge from the regular oscillation of Old/New that makes up the jeremiad of "American" politics.

But how can one reasonably believe in this "possibility" or practice a discipline whose forms of rationality allow for such imaginings? I do not ask this question to object that Bercovitch seems to offer neither a plan for bringing it about nor a theory of agency that would account for the desire. I ask it, rather, to draw attention to the fact that one can believe in this possibility only if one accepts Bercovitch's theory of "consensus" and "dissensus" formation --in other words, his model of inner and outer, self and other, old and new-- a model of rationality we should all recognize as problematic. In other words, one must first accept this possibility as such, even as utopian desire; and that acceptance depends, in turn, upon working within an institution and discourse that aligns a form of reason and forms of power in ways that allow individuals to speak of these matters, that determine what "American" literature and "American" critics can and might be. Michel Foucault's forceful phrase comes to mind: one must accept the "regime of truth" --in any or all of its variations-- to be in a realm where what 
is thoughtful about Bercovitch's "Americanist" vision and project makes any sense. (The hidden question, of course, is does one want to be in this regime and if so why?)

Bercovitch, as always, puts the matter eloquently, reasonably, and lucidly:

The option [for "American" critics] is not multiplicity or consensus. It is whether to make use of the categories of the culture or to be used by them. I do not claim that the essays here altogether avoid the peculiar cultural traps embedded in the quest for "America," in either its multiple or its unitary guises. Indeed, I am aware that what at the start of this Afterword I called a dialogue in the making has itself the makings, @p(in potentia), of still another example of the special genius of the rhetoric of American consensus, which is to co-opt the energies of radicalism: to reabsorb the very terms of opposition into the promise of the New, that long-nurtured vision of Futurity that carries us forever back, through a procession of sacred landmarks... to the ideological premises of modern democratic liberalism. I am aware, too, that some of the central concerns... may be even more problematic than their treatments in this volume suggest. (A 438 - 39)

If Bercovitch seriously means that critics must either "make use of the categories of the culture or... be used by them," he repeats an authoritative blunder that restricts "criticism" to endless repetition. It would be interesting to ask how it came to be possible that Bercovitch could put the matter in terms of this unquestioned dualism. For a moment, let us rather think some of the consequences of what he has allowed himself to say: we have to imagine that critics --and all others, intellectuals in their own work, wherever that might be-- are either always nothing more than the unquestioning agents of already inscribed categories; or, that somehow what privileges critics, indeed establishes their identity as such, is their ability to escape this determination and, by means of the knowledge of the categories, no doubt acquired through the practice of the "Americanist" discourse, not only to rise above them but put them to some use --a use which, in itself, transcends, is outside, the ideological realm made up and disseminated by those

very categories. But we have seen that Bercovitch's claims cannot be taken seriously without wondering what it is that allows him to propose such a simple opposition. Training as an "Americanist," as a "cultural critic" of his sort would not provide the grounds for choosing not to be a victim "of" the culture's categories. So what would be the source of the values and desires that would direct the operation of this critical use of the categories and where would they originate if not also in and from the ideologies and powers of these "Americanist" discourses? And why should one assume that these 
discourses provide a set of possibilities to "use" rather than "be used" when the correlations between this discourse and its culture have not yet been made clear? Why assume these categories have any liberating possibilities at all when, as we see them at work in Bercovitch's "oppositional" practice, they allow him to deceive himself about the "freedom" he has to choose the model he proposes? To put it simply, what would be the source of this free critic's authority and whence such a critic?

So let us not quibble with Bercovitch's formulation; he certainly could not mean it if he thought more about it. Let us rather ask what it means that the thought was available to him; or, rather, that, in this context, he felt it desirable to enact such an emprisoning representation of critical possibility --in direct contradiction to his voiced desire.

One can find a partial explanation for the appearance of this representation in the logic that interweaves Bercovitch's own professional, institutional position and the discourse of "American Studies." A detailed placing of that discourse is beyond the reach and purpose of this essay; but it is clear enough to say that it allowed Bercovitch to choose to study the "jeremiad" as a "cooptation" theory of "American" radicalism whereby all challenges to the "American" consensus shatter in the face of "America's" rhetorical, political uniqueness: "to reabsorb the very terms of opposition into

the promise of the New." Donald Pease has laid out the consequences of this position.[12] Bercovitch's view of "America" as a "jeremiad," as a cultural machine for producing political "consensus," makes him suspicious of all critical claims to begin again, to stand outside the terms of debate. The logic of this suspicion, so the argument goes, is that one must postulate the possibility of being within that culture in order knowingly to use its very categories against itself. (The only other alternative -- one Bercovitch does not examine --is to offer something "really new" which is itself, precisely, just the latest, empowered version or transformation of what has always come before.) The paradox is that we are to assume this is a potential of the very same device that manufactures consensus; but we know it cannot be so; in fact, the user of a culture's categories must emerge as the specular alternative to the dominant forms of "America," as its ghastly (spiritual) other somehow "in the world," as the Church Fathers would have it, but equally somehow not "of the world." In critical terms, we would say that not to be used by the culture means being beyond or outside it. This is what we sometimes call metaphysics and it is a problem that theory has spent considerable time dealing with over the last twenty years.[13] It is also a problem that, cast in these terms, cannot be taken seriously in that no one can ever be "free" of the order of rationality of the time or of that order's relations --as technologies and practices, as intermediate rules of social combination-- to the largest orders of power in a society.[14] 
Bercovitch's institutional power and scholarly, critical decorum - --the style of his writing and career-- make him "representative" within "American Studies." At this moment, one can best see much of what "American Studies" traditionally allows one to choose to be as a critic by reading as closely as possible the work of precisely its most accomplished and thoroughly institutionalized figure. His "originality" lies, as it were, in his most fully extending the possibilities of his chosen discipline. One can read his text to say something about the empowered rationality of the very discourse he helps to extend and redefine; one can talk about how it exists, as he puts it, "in its theoretical fullness" (A 438). The process is doubly interesting in part because Bercovitch takes it as a central part of his task to reflect upon the ideological consequences of the workings and techniques of this discourse in its society. As he elaborates on it, this critical and scholarly discourse seeks the "American" dream in "American" literature; it continually realigns "classic literary" and ideological forms of representation; it involves the all too common occurrence of a radical criticism emerging in relation to professionalized "American" institutions. "America" has produced, according to Bercovitch's figure of the "jeremiad," no radical discourse --aimed at "renewing" this culture gone wrong-- that has not, because of its very desires, lost its energies in the mainstream of "American" culture, business, and politics. Hence Bercovitch's own desire to see in the essays of the "New Americanists" the possibility of "alternative" forms of historical study and representation --alternatives that will not, as it were, always already be positioned to become part of the consensus of "America."

Bercovitch's vision of the peculiarly "American" nature of the problems facing any radical emergent culture helps identify the limits of actually existing "American" criticism:

I think, for instance, of the problem of locating our radical tradition in a literature obsessed with an American dream; or of the problem of locating that dream, considered

as our radical tradition, in the realm of literature; or again, of the problem of locating a radical discourse about American culture in what is after all a rather traditional exchange among professional literary critics. (A 439)

\footnotetext{
"Americanist" criticism has, in Bercovitch's view, made too much of the literary, taking it perhaps uncritically as the privileged site of cultural resistance to the oppression of US society. In other words, this professionalized debate among academic literary scholars may, indeed, have invested the literary with a liberatory, critical possibility that there is no prima facie reason to believe it actually possesses. Or, to put the matter mildly, the literary --as represented by these academic "Americanists"-- may
} 
not be the best evidence for the possibility that a radical alternative to the dominant order of "American" oppression, of the "ideologues and their victims," actually exists, has existed, or can ever exist in US life and economy (A 428). The critical error may lie in decoding or interpreting "American literature" as the expression of a dream for a better "America." This is not to say that this literature should be read as a collaborative enterprise, or even one in a mixed or dialectical relation to the oppressive and non-literary. It is simply to say that the institutionalized discursive practice, the habits and procedures, of "Americanist" work have led to the consistent representation of "American literature" as an embodiment of utopian hopes, of aspirations for a fulfillment or recovery of lost dreams --or simply as a reservoir of unfulfilled potentialities.[15] "Americanist" discourse, in these simple terms, are part and parcel of the operations of "America." The discourse re-establishes "America" as the vision of the New; the discourse has legitimacy --no matter how critical it may be of actually existing US society-- only in an affirmative relation to "America" as the process of national self-affirmation and international self-assertion.

We can imagine alternative ways to conceive the critic's relation to culture so that the binaries that emerge in Bercovitch's work do not define a dilemma --but not, I would argue, unless the very nature of "Americanist" discourse is overhauled so totally -- or perhaps put aside so thoroughly-- that it might not be recognized as "Americanist" at all. But is this a possibility? Operating within the boundary of "Americanist" discourse, trying, as they say, to "subvert" it from within --it is against the seemingly easy possibility of this tactic that Bercovitch warns us. Stepping "outside" this boundary? How does one do this when "American" literature and culture have come to be represented as they are by an "Americanist" discourse so aligned with the operations of its own "cooptation" that that literature cannot possibly be seen again "for the first time"? But how can one use the categories of the culture against itself when these categories, these sets of representations and their systematic and asystematic organization are as powerful as they are, when they are so essential to making the critic who thinks he wants to be beyond them? What one would need to succeed as this transcendence would be a theory or myth of the self-originating critical mind. Or, at least, one would need a theory of the critic as "master" of the discourse(s) that have made that critic expert and competent. What would be the grounds for imagining such a critic in this day and age? And what would such a critic have to do?

That Bercovitch dedicates another of his edited volumes, Reconstructing American Literary History, "To the Memory of F. O. Matthiessen and Perry Miller," can be understood in several ways, any one of which might partially answer these questions.[16] In one sense, Bercovitch is the institutional successor to these luminous figures at Harvard so the dedication is appropriate; in another sense, suspending consideration of their institutional position for a moment, these two men were the leading figures of their discipline, critics and historians whose founding and 
revisionary texts were authoritative and are, even today, the object of constant reconsideration. In any event, this dedication is a gesture of succession, of continuity with the master critics of the past.[17]

Is it true that "American Studies" seems to have had greater need for these authoritative critical masters and their texts than most other subdisciplines of modern literary study? If so, the reasons would not be hard to understand: the literature needed a founding authority; the nation needed its identity and continuity; in part both were provided by the professionalized, institutionalized success of the discipline in elite private, state, and state-related universities: this structure generates masters necessary to maintain discipline and necessary to the power formations of training, rewards, and discursive regularity: leaders also align the discourse properly with the supporting state apparatuses. Not only in his own writing, but in his massive and maieutic editorial enterprises, Bercovitch plays this role of the master in wonderful parts: I have focused so much on the "Afterword" to Ideology and Classic American Literature precisely because the essay exemplifies the power operations I am suggesting: summoning new essays, reprinting already published pieces, asking for "reconsiderations" from older "masters," this "Afterword" positions not only a new generation in relation to an old -- and mark how the inclusion of "old" masters means that generation here is a professional and not chronological category - --but all the new in relation to his own sense of all relations between new and old and all these and his own sense of what, as midwife, he seems to want to aid in delivering: "alternatives."

Taking his position seriously --precisely as it is marked by his dedication to Miller and Matthiessen-- means that his work can point beyond itself, to what needs to be, but, as I see it, cannot be done within that enabling discourse of "Americanist" criticism. It seems to me implicit, for example, throughout the resonant and sometimes knotty work of Jonathan Arac, perhaps the most brilliant young contributor to the new Cambridge History of American Literature that Bercovitch is editing --it seems implicit throughout Arac's work that the "Americanist" position on matters "American" cannot be sustained; from Commissioned Spirits through Critical Genealogies to "'A Romantic Book': Moby Dick and Novel Agency," Arac -perhaps like Matthiessen before him-- has tried for an internationally comparative position on "American" literature of a sort that simultaneously accords the historical, geographic specificity of the conditions of cultural production their full weight while neglecting neither the "global" nor theoretical view of the putative "American" subject at hand.[18] So the key, as it were, to Arac on Melville lies in Schlegel and Goethe! Arac's example can, of course, be compounded. Donald E. Pease is another instance of the limits of "Americanist" criticism; his work exemplifies another response to its crisis: Pease has so thoroughly made his own the work of Habermas and his predecessors that his vision of "America" is, we might say, as European as it is "Americanist." Bercovitch's writing points to this need in "Americanist" criticism and to his own hopes for a criticism beyond the 
"national." There is no doubt, I think, that the strictly "national" focus of "Americanist" criticism cannot be sustained; indeed, Richard Poirier has made a point of criticizing the "parochialism" of this criticism in a recent essay in The London Review of Books: The result [of such nationally focused criticism] is a stifling parochialism exactly where there is most need for comparative studies involving other literatures of much longer duration. Principally, this has to mean literature in English... Those who refuse... to inquire into "the Atlantic double

cross"... are not able in an effective way to speculate on a phenomenon of immense consequence.[19] Arac, Pease, and the others engaged in similar projects suggest the sort of paradigm shift that Poirier obviously feels is essential to provide the "New Alternatives" Bercovitch requires.

But if we recall our Foucault, if we recall the Gramsci with whose words I began this paper, we would understand that the radical change in the "regime of truth" necessary to shift us beyond the iterations of "American Studies" cannot occur without both a genealogical critique of the emergence of that discipline and its discourses (or the discourses which generate it; the question of priority is open) and a political theorization of the relation not just of the ideology but of the discursive and institutional relations of "Americanist" criticism --even in its oppositional moments-- to the larger systems of representation essential to State and other forms of power in our imperial and oppressive cultural, social order.[20] Of course, such a set of critical investigations would require borrowing critical tools from any number of places other than "American Studies." It would also mean a willingness to theorize the discourse with no advance regard for its "accomplishments." This is not to say, however, that such theorization should have no interpretive sympathy for the its objects: minus that sympathy even the critical understanding necessary to struggle cannot be achieved.[21]

A critical genealogical awareness of "American Studies" as a set of established and oppositional discourses and disciplines must be achieved if the criticism of United States literature and culture expects to distance itself enough from its determinant affiliations and its regulating rationalities to gain some control over the means of intellectual production inherited from the past and entangled with other practices and ideologies in the present. Of course, we must recognize the conundrum in what I am suggesting. The study of United States literature and culture cannot transpire without drawing on the textual, historical, and critical resources established in the disciplines of "American Studies." More important, a critique of these disciplines and their cultural, political placement cannot occur without the enabling, authorizing, empowered devices and insights provided by a number of critical discourses often affiliated with "American Studies" itself. As an example of the sort of problem that faces the intellectual selfconsciously carrying out such a project, one thinks immediately of the similarities between "American Studies'" involvements with myth, typology, and historicism and the historicist edge to genealogical critique. As I see it, however, these problems need to be taken not as limits, but as occasions and 
opportunities for reflection upon the issues that arise in attempting to carry out a critique with instruments entangled in the very "regime of truth" under investigation. One wants to say that such problems are occasions for genealogical, theoretical reflection upon "American" literature and culture as constructs of United States society; upon the formation by that society of the established and oppositional "Americanist"; upon the position of any agent attempting to carry out such a reflection, a reflection --we must repeat enabled, in part, by those discourses themselves-- upon the needs of the present that

encourage, make possible, require, or call forth such reflection.[22] Perhaps the demise of the Cold War and the weakening of "American" imperialism in a time of different global relations of power, race, gender, economy, and technology so alter the position of any "critic" that a set of complexly polyvalent, perhaps kaleidoscopic reflections and discourses alone can provide the conditions of critical practice.

Following Erich Auerbach, Edward W. Said has made much of the fact that the critic must be distanced from a dominant culture, must be an "exile."[23] That "exile" is the appropriate emblem for critical distance reflects a complex understanding of the material workings of "culture":

I shall use the word culture to suggest an environment, process, and hegemony in which individuals (in their private circumstances) and their works are embedded, as well as overseen at the top by a superstructure and at the base by a whole series of methodological attitudes. It is in culture that we can seek out the range of meanings and ideas conveyed by the phrases belonging to or in a place, being at home in a place... culture is used to designate not merely something to which one belongs but something that one possesses and, along with that proprietary process, culture also designates a boundary by which the concepts of what is extrinsic or intrinsic to the culture come into forceful play... But... there is a more interesting dimension to this idea of culture as possessing possession. And that is the power of culture by virtue of its elevated or superior position to authorize, to dominate, to legitimate, demote, interdict, and validate: in short, the power of culture to be an agent of, and perhaps the main agency for, powerful differentiation within its domain and beyond it too... What is more important in culture is that it is a system of values saturating downward almost everything within its purview; yet, paradoxically, culture dominates from above without at the same time being available to everything and everyone it dominates. [24] 
One must not only understand national and regional "cultures" but also their interrelations and relations to "metropolitan" cultures in an imperial (whether colonial, post-colonial, neocolonial, or decolonizing) order to understand how differentiated the distantiation of critical exile has come to be.[25] Auerbach could write Mimesis in Turkey because his distance from libraries allowed the synthetic point of view on the topic of "realism" that defines that book. But when culture becomes so clearly a set of processes and values that define and enable both that culture's defenders and its opponents, that is, like Satan's hell, always in our hearts --then the possibility of exile becomes harder. One must be in exile in relation not only to the national, but to the regional, local, and international effects of culture as well. Auerbach lets Said quote Hugo of St. Victor to the effect that exile and therefore critical perfection depends upon taking "the entire world as a foreign land." This remarkable asceticism in the face of the restrictive, but enabling, ravages of imperial nationalism --whether Roman, German, or American-- makes it possible for the critic to occupy the paradoxical position of worldly transcendence, the old Christian position of "being in the world, but not of it." Or, to put it somewhat differently, "exile," as ascesis, is a demanding discipline of critical self-making.[26]

While honoring the values of distance and the experiences of exile that theorize it as a critical necessity, one must also wonder if the study of culture does not require an even more complex and difficult position: being in and of one's locale while understanding its needs and hence one's own projects in terms of a global or transnational set of interlocking perspectives: the best critical emblem for our time might be what Gayatri Spivak has taught us to call the "post-colonial subject," that is, the gendered intellectual engaged in agonistic analysis of global issues central to regional and national concerns and always motivated by an understanding of the complex position that any citizen of a postmodern cultural multiplicity must occupy.[27]

I want to suggest too crudely that "American Studies" taken as a field in its "theoretical fullness" --I realize this formulation occludes specific differences-- has not yet reached the point of "exile" in relation to itself and its nationalist projects. This is an intolerable situation to be in because, like it or not, the citizens who carry out even "New Americanist" discourses do so precisely as persons whose own positionality --despite the appearance of their practice-- is not solely determined or defined by their inscription within the professions that trained them (pace Stanley Fish!). This has, of course, always been true - as any look at the monuments of the subdiscipline would show. But it is intensely true now precisely because the historical multipositionality of the critic is a determining "fact" that has already been partly theorized within criticism in the work not only of Spivak, but of Foucault, Gramsci, and others. 
Jürgen Habermas makes an important point in his recent essays within the Historikerstreit. Commenting on his own authority to oppose Andreas Hillgruber's study of the German Army on the Eastern Front -- despite his non-expert status -- Habermas claims his right to intervene as a citizen affected by the public consequences of Hillgruber's and others' works: "I am thus making the self-observations of a patient who undergoes a revisionist operation on

his historical consciousness."[28] In other words, Habermas implies that professional academic productions emerge into general culture along vectors constructed and kept open by the ideological and institutional operations of the dominant powers within our societies. The intellectual -both in the specialized sense and the Gramscian sense of "everyman"-- not only has the right to intervene in the so-called "debates" that travel along these vectors and, in the process, make up some important parts of our political, ideological culture, but also the obligation to intervene given that the arrogant task assigned to the producers of institutionalized knowledge -- especially of a historicist kind-- is, as Habermas puts it, "to treat historical consciousness as a maneuverable mass in order to provide suitably positive pasts for the legitimation requirements of the present political system."[29] Of course, one sees in this remark some of the characteristic flaws in Habermas's own sense of the oppositional: it is not merely a matter of the "contents" of the "representations" of the "past" that should be our concern -- although no doubt it makes a crucial human and political difference if World War II is seen as a common war against Bolshevism or not-- but of the structure of a persistent system, of our new social order, that, as such, needs a certain relationship between State, governments, ideologies, and varying sets of ideological representations not only for its survival, but also, in the fullest sense of the word "hegemony," for its mastery of all possible forms of

radical opposition short of "revolution."[30] We might say in this context that Bercovitch has mistaken "hegemonic" operations of the extended State for "America": an understandable error, perhaps, but one that should not be repeated.

"American Studies" has always had admirable, important, and powerful oppositional figures and practices within and adjacent to it. In recent years, especially in its historicist, feminist version, revisionist critics have powerfully and crucially recovered the progressive energies of these figures and advanced the rights and identities of women and other minorities within the "American" socius and tradition. The work of Bercovitch and others, however, has reminded us of how "American" ideology and "American" discourses and institutions seem particularly well-suited to disarm these radical challenges by bringing them within the "pluralistic" economy of everyday political conflict and debate, the sort of struggle that goes on 
always within a "liberal" State-system. Gramsci, however, has helped us further to understand that unless the "opposition" to a given "hegemony" attempts to build a counter-hegemony, to resist encirclement by the hegemonic institutions, the fate awaiting that "opposition" can be anticipated in the strategy of "passive revolution": "the gradual but continuous absorption, achieved by methods which varied in their effectiveness, of the active elements produced by allied groups --and even of those which came from antagonistic groups and seemed irreconcilably

hostile."[31] In other words, critical work must be directed at or against the present; let it emerge, if it must, from a historicist sense, but let it always be, as Foucault says, "a history of the present." [32] The issue must always be the placing of "Americanist" work in the contemporary national and world order --a placing that puts at risk not only those terms themselves, but also the disciplines and knowledges built up as the condition for the critical engagement with the present. To put the matter bluntly one must say that merely historicist studies such as those of the "emergence of the bourgeois self in post Civil War laissez-faire economics" matter hardly at all unless they are directed against both the present relation of the "regime of truth" to the structures of power and exploitation as well as all social, political elements that block the recovery of the "demiurge" of which Gramsci speaks so eloquently.[33]

I am suggesting that the critical preservation or reform of the discourses and institutions of "American Studies" is analogous to capitalism's maintenance of a stable work force, a certain "equilibrium," the collapse of which would threaten both the workers, who fear the loss of the only order they know, and the capitalists, whose dominance depends upon the workers' inter-nalization of that equilibrium. "Passive revolution" prevents the dismemberment of the discourse and its institutions; it encourages their "transformation," a notion that must be seen in the sense Foucault gives it in Discipline and Punish where he refuses the rhetoric of metaphysical agency and causality to mark the anonymity of power's operations.[34] Gramsci speaks of "puritanism" as an ethic essential to control of the "American" worker; we need only recall the State led assault on "drugs," the critical invocations of "ethics," [35] and recent calls by high government

officials for more Puritan values of hard work and saving to have a sense of certain alliances between cultural institutions and the State's capitalist roles.

Criticism of "American" culture must set out to have the present as its subject and cannot proceed to any high form of criticism of the institutions of culture and the State without considered and consciously politically motivated examinations -- descriptive and theoretical-- of the "regime of truth" to which such criticism has and continues to belong. "American Studies" cannot change its paradigm simply by thinking it is treating new 
topics or loosening up the canon. It must change its own relations to the present but must first attempt to know them and to know its own place within relations as these develop the technical empowerment of specialized "critical" intellectuals. Without such theorized, material forms of knowledge, politically directed at a remaking of the regime of truth, such criticism does not deserve the name. At most it remains "scholastic" or "academic" in the weakest and most pejorative senses of those words. Criticism cannot and should not attempt to prescribe or even imagine the future, but it can and must take aim at the unequal, imperial, antidemocratic present if its work is to be of use to anyone in our world. Critics should never be good company.

\title{
University of Pittsburgh
}

\author{
Dept. of English
}

Pittsburgh - PA 15260 - US

Surface Page d'Acceuil/Home Page

[1] See Paul A. Bové, Intellectuals in Power (New York: Columbia University Press, 1986).

[2] See, for example, Burke's "progressive" 1937 article, "Literature as Equipment for Living," reprinted in Contemporary Literary Criticism, 2nd ed., eds. Robert Con Davis and Ronald Schleiffer (New York: Longman, 1989), pp. 76 - - 81; see also Wayne Booth's The Company We Keep: An Ethics of Fiction (Berkeley: University of California Press, 1988)

[3] A detailed and extended study of Bercovitch's work taken as a "career" is beyond the scope of this essay. It would however allow one to see his writings as interventions within politically contested, cultural cathected structures of "truth-production."

[4] "Afterword," in Ideology and Classic American Literature, eds. Sacvan Bercovitch and Myra Jehlen (Cambridge: Cambridge University Press, 1986), p. 428; hereafter cited in my text as A. I am not treating Myra Jehlen's work in this essay not because it is unimportant, quite to contrary. It embodies powerful feminist revisionist criticism and scholarship the relation of which to the image I am trying to summon from Bercovitch's work cannot be adequately dealt with here -- since it is the dominant discourse I am trying to discuss. The already classical revision of Bercovitch's position can 
be found in "New Americanists," ed. Donald E. Pease, boundary 2: 17, 1 (Spring 1990).

[5] See Frederick Crews, "Whose American Renaissance?", in The New York Review of Books, 35:16 (27 October 1988): 68 - 69. See Donald E. Pease's irrefutable explanation of Crews's position, "New Americanists," boundary 2, 17, 1 (Spring 1990): 1 - 37.

[6] For a listing of many of the most important works, see the notes to Bercovitch, pp. $439-42$.

[7] Perhaps one can distinguish certain sorts of "American" feminism from some of the more theoretically inspired European versions by noting the difference between "andro" and "phallocentric." The latter term depends upon the Lacanian rereading of Freud in the light of semiotics; the former seems more empirically motivated, associated with anthropology. The difference is not universal but see in the context of Emily Dickinson and Adrienne Rich, Patrocinio Schweikart's prizewinning essay, "Reading Ourselves: Toward a Feminist Theory of Reading," in Gender and Reading (Baltimore: The Johns Hopkins University Press, 1986), pp. 31 - 62

[8] F. O. Matthiessen, The American Renaissance (New York: Oxford University Press, 1941).

[9] "American 'Left' Literary Criticism," in The World, the Text, and the Critic (Cambridge: Harvard University Press, 1983) p. 175.

[10] Arac offered this direct formulation in conversation; see also his Critical Genealogies (New York: Columbia University Press, 1987), pp. 32, $169 f$.

[11] For some discussion of the dangers of "pluralism" to criticism in the United States, see Bercovitch, p. $438 f$.

[12] For a powerful critique and alternative view to Bercovitch's, one that is as extensive and eloquent, see Pease, Visionary Compacts (Madison: University of Wisconsin Press, 1987).

[13] See Gilles Deleuze, Foucault, trans. Sean Hand (Minneapolis: University of Minnesota Press, 1988).

[14] See Michel Foucault, "The Political Technology of Individuals," in Technologies of the Self, eds. Luther H. Martin et al. (Amherst: University of Mass. Press, 1988), pp. 145 - 62.

[15] That this is quite ordinary in national traditions can be seen from the work of Benedict Anderson, Imagined Communities (London: Verso, 1983).

[16] Harvard English Studies 13 (Cambridge: Harvard University Press, 1986).

[17] For some analysis of this figure of the masterful intellectual, see Bové, Intellectuals in Power. 
[18] Arac, Commissioned Spirits: The Shaping of Social Motion in Dickens, Carlyle, Melville, and Hawthorne (New Brunswick: Rutgers University Press, 1979); Critical Genealogies: Historical Situations for Postmodern Literary Studies (New York: Columbia University Press, 1987); "'A Romantic Book': Moby Dick and Novel Agency," boundary 217 (Winter 1990).

[19] "American Manscapes," The London Review of Books, 12 October 1989: 18.

[20] One should again see Arac's essay on Melville, which, in part, is a study of the possibility of agency, as an instance of this project.

[21] See Daniel T. O'Hara, "The Poetics of Critical Reading," in Poetics Today, forthcoming: "the productive power of critical reading must be balanced by an appreciation for the achievement being read" (mss p. 20).

[22] For the beginnings of critique of the value and function of "reflection," recall Kierkegaard's critique of reflection in Hegel. For a discussion of this issue, cf. Paul A. Bové, "The Penitentiary of Reflection: Sören Kierkegaard's Critical Activity," boundary 29 (1980): 233 - 58; reprinted in Kierkegaard and Literature, ed. Ronald Schleifer (Norman: University of Oklahoma Press, 1984), pp. 3 - 35.

[23] Edward W. Said, "Secular Criticism," in The World, the Text, and the Critic, pp. 8ff. See also Bové, Intellectuals in Power, pp. $271-75$.

[24] Said, "Secular Criticism," pp. 8 - 9.

[25] Think, for example, of how complex the differentiation must be when the term "exile" describes or points to enabling conditions in intellectuals as different as Auerbach and C. L. R. James. See James, The Black Jacobins: Toussaint L'Ouverture and the San Domingo Revolution, 2nd ed., rvsd. (New York: Random House, 1963); originally published in 193X). See also Said, "Nationalism, Colonialism, and Literature," in A Field Day Pamphlet No. 15 (Derry: Field Day Theatre Company Limited, 1988), esp. p 6ff.

[26] See Michel Foucault, "the ethic of care for the self as a practice of freedom," trans. J. D. Gauthier, S. J., in The Final Foucault, eds. James Bernauer and David Rasmussen (Cambridge: MIT Press, 1988), p. 13; the interview was conducted on January 20, 1984.

[27] Spivak rightly catches the oppositional edge in laying out this sort of criticism in "Explanation and Culture," in In Other Worlds (New York:

Methuen, 1987), pp. 103 - 17; see esp. p. 109 where Spivak discusses the relation of critics to the culture as mediated through the university: "individuals in the chosen profession of humanists can only be tolerated if they behave in a specific way... (1) to reproduce explanations and models of explanation that will take so little notice of the politico-economicotechnological determinant that the latter can continue to present itself as nothing but a support system for the propagation of civilization (itself a species of cultural explanation)... (2) to proliferate scientific analogies in socalled humanistic explanations... (3) at the abject extreme, the open 
capitulation at the universities by the humanities as agents of the minimization of their own expense of production."

[28] "A Kind of Settlement of Damages," trans. Jeremy Leaman NGC 44 (Spring/Summer 1988): 25 - 39, esp 29; see also in the same issue of NGC, Habermas, "Concerning the Public Use of History," 40 - 50. To put these essays in context, see Charles S. Maier, The Unmasterable Past: History, Holocaust, and German National Identity (Cambridge: Harvard University Press, 1988), esp. pp. 9 - 33.

[29] "Settlement of Damages", 28.

[30] It was precisely Gramsci's intent to theorize this state of affairs in regard to the 19th century that led him to formulate the still crucial notion of the "passive revolution." See Selections from the Prison Notebooks, ed. and trans. Quintin Hoare and Geoffrey Nowell Smith (New York: International Publishers, 1971), pp. 106 - 08.

[31] Selections from the Prison Notebooks, p. 59. See also Partha Chatterjee's comments on "passive revolution" in Nationalist Thought and the Colonial World (London: Zed Books, 1983), esp. pp. 50 - 52.

[32]On some of the dangers in certain historicist projects see Donald E. Pease, "Greenblatt, Colonialism, and New Historicism," in Some Consequences of Theory, eds. Jonathan Arac and Barbara Johnson, English Institute Papers (Baltimore: The Johns Hopkins University Press, 1990), pp. $\mathrm{xxx}-\mathrm{xx}$.

[33] Gramsci, in Notebook 8, note 150, writes of the "demiurge" in its "original sense" as "one who works for the people, for the community (artisan)" and points out that this precedes and underlies the modern sense of the demiurge as the "creator." Here I translate from the French edition of the Quaderni, Cahiers de Prison, books 6 - 9, trans. from the Italian by M. Aymard and P. Fulchignoni; ed., annotated, and introduced by Robert Paris (Paris: Éditions Gallimard, 1983), p. 343. My thanks to Joseph Buttigieg, who is preparing the English edition of the Notebooks, for pointing out this note.

[34] Discipline and Punish: The Birth of the Prison, trans. Alan Sheridan (New York: Pantheon Books, 1977), esp. pp. 80ff.

[35] See, among many recent books, Wayne C. Booth, The Company We Keep: An Ethics of Fiction, p. $\mathrm{x}$ where Booth tells us it is his aim "to restore the full intellectual legitimacy of our common-sense inclination to talk about stories in ethical terms." We need not note at any length that throughout this commonsensical book intended for specialist and "general reader" alike, the former President of the MLA thinks he carries out this restoration without even bothering to mention the most rigorous and important critic of the notion of "common-sense" in current discourse, Gramsci. Perhaps this is simply another example of the grace all "moderate pluralists" possess not to be complete in their scholarship. On this Gramsci has a good point: "Scholastic activities of a liberal or liberalising character have great significance for grasping the mechanism of the Moderates' hegemony over 
the intellectuals." It is one of the few avenues "open to the initiative of the petite bourgeoisie". (Prison Notebooks, p. 103.) 